\title{
Early childhood teachers' perceived barriers to ICT integration in teaching: a survey study in Mainland China
}

\author{
Xia Liu - Jenny Pange
}

Received: 28 October 2014/Revised: 8 December 2014/Accepted: 13 December 2014/

Published online: 28 December 2014

(C) Beijing Normal University 2014

\begin{abstract}
This paper looked at the barriers to ICT integration in teaching practices from the perspective of Chinese early childhood teachers in Mainland China. A total of 46 Chinese early childhood teachers in Mainland China participated in this study. They were from three early childhood settings located in three different cities in terms of the administrative division. A self-designed questionnaire was adopted as the research instrument. It was found that a range of first-order barriers, which included lack of hardware (laptops, notebooks, and computers), lack of teaching content and material, as well as lack of pedagogical models were perceived as main barriers by the teachers. However, several second-order barriers, such as lack of teachers' interest, and lack of teachers' support were perceived as the least main barriers. Furthermore, the variable "ICT use in daily life" was found play an important role in determining the teachers' perceptions of barriers both on the overall level and on the specific level. Several recommendations for future practices and research were also provided.
\end{abstract}

Keywords ICT integration · Barriers · Teaching practices ·

Early childhood teacher - Mainland China

\section{Introduction}

Since the 1980s, as the advance of modern information and communication technology (ICT) and the increasing acknowledgment of the value of ICT on

\footnotetext{
X. Liu $(\bowtie) \cdot$ J. Pange

Laboratory of New Technologies and Distance Learning, Department of Early Childhood Education, School of Education, University of Ioannina, 45110 Ioannina, Greece

e-mail: liux825@hotmail.com

X. Liu

School of Education, Northeast Normal University, Changchun 130024, Jilin, China
} 
teaching and learning, a number of countries have introduced ICT into their educational systems (Al-Senaidi et al. 2009; Ihmeideh 2009; Khan et al. 2012; Goktas et al. 2013; Blackwell et al. 2014). They carried out a series of initiatives, programmes and investments to promote the process of ICT introduction and integration in the educational field (Pelgrum 2001; Kozma 2008). These efforts have led to substantial outcomes, particularly in terms of the establishment of ICT infrastructure, and the improvement of teachers' ICT-related knowledge and skills.

However, these achievements can still not meet people's high expectations of ICT for teaching and learning (Buckingham 2007; Blackwell et al. 2013). A range of research has pointed out that although teachers held positive attitudes toward ICT for teaching and learning, and also had much enthusiasm to integrate ICT into teaching (Wood et al. 2008; Ihmeideh 2009; Bingimlas 2009), they did not frequently use ICT in their day-to-day teaching practices (Redecker 2009; Blackwell et al. 2013; Liu et al. 2014). Some teachers may use ICT in the purpose of teaching, but they could not achieve appropriate and effective integration practices (Redecker 2009; Blackwell et al. 2014).

One of the main reasons is that when teachers intend to introduce and integrate ICT in their teaching practices, they will encounter a range of barriers with which they do not know how to cope (Pelgrum 2001; Bingimlas 2009; Ihmeideh 2009; Goktas et al. 2013). Thus, it is of significance to identify these barriers and to find out how to overcome them, which will be helpful to enhance not only the quantity but also the quality of teachers' ICT integration in their teaching practices.

Early childhood teachers, which are an integral part of the whole teacher group, are also experiencing various barriers in their ICT integration process. Most of these barriers have similarity with those in other educational contexts (Blackwell et al. 2013; Nikolopoulou and Gialamas 2013). On the other hand, due to the particularity of early childhood education, the less attention paid to early childhood education by governments, as well as the influence of historical debate on the place of ICT in young children's learning and development (Wood et al. 2008; Ihmeideh 2009; Blackwell et al. 2014), early childhood teachers may encounter several distinct barriers. Hence, it is necessary to specifically explore the barriers challenging early childhood teachers in the process of ICT integration in teaching, to which has been given less attention by researchers.

Furthermore, compared with developed countries, the introduction of ICT in the educational field is relatively late in developing countries (Pelgrum and Law 2003). This leads to the result that the levels of access to and integration of ICT by teachers may vary between developed countries and developing countries. It was reported that the quantity and quality of ICT introduction and integration in teaching was much higher in developed countries than that in developing countries (Khan et al. 2012). Therefore, some researchers argued that developing countries could benefit little from integrating ICT in the teaching process (Khan et al. 2012). Further, several political, economical, social, and cultural factors may also play important roles in the ICT integration for teaching among countries (Al-Senaidi et al. 2009; Khan et al. 2012). It can be said that the barriers to ICT integration encountered by teachers may be very different from one country to another, due to not only the 
introduction stage of ICT in education, but also the context which it is introduced (Alwani and Soomro 2010).

\section{Literature review}

ICT integration in early childhood teaching

The introduction and integration of ICT in early childhood teaching has long been debated by researchers (Ihmeideh 2009; Blackwell et al. 2014). Many researchers support the integration of ICT in early childhood teaching, because they argued that ICT integration in teaching was beneficial for children's learning and development. These benefits are reflected in many aspects, including language and emergent literacy, mathematical thinking, creativity, problem solving, personality, communication and collaboration, as well as positive attitudes toward learning (Umayahara 2014; Evangelopoulou 2014). On the other hand, there are also some researchers discouraging the integration of ICT in early childhood teaching, particularly for the very young children. The most mentioned concerns from these researchers refer to children's health, harmful digital content, children's privacy, as well as children's isolation from the society and real-world (Umayahara 2014). The American Academy of Pediatrics (2013) even recommended that no screen time was provided to the children under age 2 , and no more than 2 hours to older children.

However, as the rapid development of ICT and the ubiquity of ICT in young children's life, an increasing number of researchers have realized that the current issue should not be focused on whether to integrate ICT into early childhood teaching, rather on how to appropriately and effectively integrate ICT into teaching to promote children's learning and development (Nikolopoulou and Gialamas 2013). For this purpose, National Association for the Education of Young Children and the Fred Rogers Center for Early Learning and Children's Media (2010) issued one joint position statement, recommending that early childhood teachers needed to use modern technologies and interactive media "intentionally" and "appropriately". Some other researchers also suggested that early childhood teachers should use ICT in an "attentive, thorough and knowledgeable" way (Evangelopoulou 2014). Only then could the potential risks of integrating ICT in early childhood teaching be minimized or eliminated, and at the same time could the benefits of ICT be maximized. From this sense, this new perspective appears to harmonize the opposite views in the historical debate.

ICT integration in early childhood teaching in Mainland China

The effort of Mainland China to introduce ICT into the educational system started much later than developed countries (Liu et al. 2014). The priority of this process has long been focused on primary, secondary, and higher education. ICT introduction and integration in early childhood education has been paid less attention by Chinese researchers. From the previous literature, it was found that ICT 
was infrequently and ineffectively used by Mainland Chinese early childhood teachers in their teaching practices, and they encountered a number of difficulties and challenges (Pu 2005; Guo et al. 2006; Liu 2007; Meng et al. 2011).

More recently, the Mainland Chinese government has begun to pay more attention to early childhood education. In 2010, it set up "early childhood education" and "educational informationization" as two of the most significant educational goals in the next 10 years (Ministry of Education of the People's Republic of China 2010). Meanwhile, the new "Professional Standards for Kindergarten Teachers" also mentioned and emphasized early childhood teachers' ICT-related competence (Ministry of Education of the People's Republic of China 2012). These political efforts from the Mainland central government are pushing forward early childhood teachers' ICT integration in teaching to a new stage.

\section{Barriers to ICT integration in teaching of general education}

Barriers to ICT integration in teaching can be defined as conditions that do not support the integration of ICT in teaching practices (Searson et al. 2011). Researchers have concluded a number of barriers teachers encountered in general education (Hadley and Sheingold 1993; Williams 1995; Leu and Leu 1997; Ertmer 1999; Pelgrum 2001; Butler and Sellbom 2002; Becta 2004; Schoepp 2005; AlSenaidi et al. 2009; Bingimlas 2009; Alwani and Soomro 2010; Tsai and Chai 2012; Chen et al. 2012; Khan et al. 2012; Goktas et al. 2013).

Ertmer (1999) classified these barriers into two groups: first-order barriers and second-order barriers. First-order barriers refer to the barriers which are external to teachers, including lack of access to hardware and software, lack of time, lack of support, and lack of teacher training. Second-order barriers are internal to teachers, involving teachers' willingness, beliefs, competences, and established classroom practices. This model has been cited by many sequential researchers (Chen et al. 2012; Goktas et al. 2013). In recent years, Tsai and Chai (2012) proposed the "thirdorder barrier"-"design thinking", which was defined as the ability to "seek to change and improve current situation and create what is desire". They also believed that teachers who were equipped with this type of ability would cope with both firstorder and second-order barriers.

From a more specific perspective, a large number of specific barriers have been documented in the previous literature. In light of the model of Ertmer (1999), these barriers can be summarized: (1) first-order barriers. It refers to the characteristics of ICT (Butler and Sellbom 2002), lack of equipment and resources (Hadley and Sheingold 1993; Williams 1995; Leu and Leu 1997; Pelgrum 2001; Becta 2004; Bingimlas 2009; Alwani and Soomro 2010; Chen et al. 2012; Khan et al. 2012; Goktas et al. 2013), lack of time (Hadley and Sheingold 1993; Pelgrum 2001; Schoepp 2005; Al-Senaidi et al. 2009; Bingimlas 2009; Alwani and Soomro 2010; Chen et al. 2012; Khan et al. 2012), lack of training (Williams 1995; Leu and Leu 1997; Schoepp 2005; Bingimlas 2009; Khan et al. 2012; Goktas et al. 2013), lack of support (technical, instructional, funding and administrative) (Hadley and Sheingold 1993; Williams 1995; Pelgrum 2001; Becta 2004; Schoepp 2005; Al-Senaidi et al. 2009; Bingimlas 
2009; Alwani and Soomro 2010; Khan et al. 2012; Goktas et al. 2013), lack of support from parent or community (Williams 1995), lack of space (Hadley and Sheingold 1993; Alwani and Soomro 2010), curriculum constraint (Chen et al. 2012), public examinations (Becta 2004), and wider economical, political, social and cultural barriers (Butler and Sellbom 2002; Khan et al. 2012). (2) second-order barriers. This group includes teachers' negative willingness and attitudes (Hadley and Sheingold 1993; Pelgrum 2001; Schoepp 2005; Bingimlas 2009; Chen et al. 2012; Khan et al. 2012), teachers' lack of confidence (Becta 2004; Bingimlas 2009), teachers' lack of knowledge and skills (Hadley and Sheingold 1993; Williams 1995; Pelgrum 2001; Becta 2004; Schoepp 2005; Bingimlas 2009; Khan et al. 2012), and teachers' established beliefs and practices of teaching (Ertmer 1999; Turbill 2001).

\section{Barriers to ICT integration in early childhood teaching}

Research on barriers to ICT integration in teaching is mainly focused on primary, secondary, and higher education. Less research has been conducted in early childhood setting (Turbill 2001; Sandberg 2002; Wood et al. 2008; Ihmeideh 2009; Blackwell et al. 2013; Nikolopoulou and Gialamas 2013), especially from the perspective of early childhood teachers.

The barriers found in early childhood setting are similar to those in other education contexts. The most mentioned barriers faced with by early childhood teachers involve both first-order barriers and second-order barriers. The first-order barriers include lack of facilities and resources (Sandberg 2002; Wood et al. 2008; Ihmeideh 2009; Nikolopoulou and Gialamas 2013), lack of support (Ihmeideh 2009; Wood et al. 2008; Nikolopoulou and Gialamas 2013), lack of training (Wood et al. 2008; Ihmeideh 2009; Nikolopoulou and Gialamas 2013), lack of time (Turbill 2001; Sandberg 2002; Ihmeideh 2009), limited classroom condition (Nikolopoulou and Gialamas 2013), and classroom management difficulty (Wood et al. 2008). The second-order barriers consist of teachers' negative beliefs and attitudes (Turbill 2001), teachers' insufficient knowledge and skills (Turbill 2001), as well as teachers' lack of confidence (Nikolopoulou and Gialamas 2013).

\section{Research aim}

The lack of evidence of barriers to ICT integration in teaching from the perspective of Chinese early childhood teachers in Mainland China provides the foundation for this study. This study aims to explore Mainland Chinese early childhood teachers' perceived barriers to ICT integration in their teaching practices. Specifically, the following research questions will be looked at:

1. What are the top barriers to ICT integration in teaching perceived by Mainland Chinese early childhood teachers?

2. How are Mainland Chinese early childhood teachers' perceptions of barriers to ICT integration in teaching influenced by their personal demographic characteristics in terms of age, teaching years, educational level, pre-service training, in-service training and ICT use in daily life? 


\section{Methodology}

\section{Samples}

A total of 46 early childhood teachers participated in this study. They were from three early childhood settings located separately in three different cities in terms of the administrative division. These cities were: (1) Beijing - the capital of China; (2) Shenyang - a provincial capital; and (3) Siping - a prefecture-level city. All the settings belonged to urban areas. The more detailed information of these teachers can be found in Table 1 .

Table 1 Demographic information of the participants $(N=46)$

\begin{tabular}{|c|c|c|}
\hline Variables & $\mathrm{F}$ & $\%$ \\
\hline \multicolumn{3}{|l|}{ Gender } \\
\hline Female & 46 & 100 \\
\hline Male & 0 & 0 \\
\hline \multicolumn{3}{|l|}{ Age } \\
\hline $21-25$ & 19 & 42.2 \\
\hline $26-30$ & 17 & 37.8 \\
\hline $31-35$ & 6 & 13.3 \\
\hline $36-40$ & 0 & 0 \\
\hline $41-45$ & 3 & 6.7 \\
\hline $46-50$ & 0 & 0 \\
\hline \multicolumn{3}{|l|}{ Teaching years } \\
\hline $1-5$ & 33 & 78.6 \\
\hline $6-10$ & 5 & 11.9 \\
\hline $11-15$ & 1 & 2.4 \\
\hline $16-20$ & 1 & 2.4 \\
\hline 21 or more & 2 & 4.8 \\
\hline \multicolumn{3}{|l|}{ Educational level } \\
\hline Doctor & 0 & 0 \\
\hline Master & 0 & 0 \\
\hline Bachelor & 22 & 48.9 \\
\hline Below Bachelor & 23 & 51.1 \\
\hline \multicolumn{3}{|l|}{ Pre-service training } \\
\hline Yes & 24 & 54.5 \\
\hline No & 20 & 45.5 \\
\hline \multicolumn{3}{|l|}{ In-service training } \\
\hline Yes & 15 & 41.7 \\
\hline No & 21 & 58.3 \\
\hline \multicolumn{3}{|l|}{ ICT use in daily life } \\
\hline Yes & 35 & 76.1 \\
\hline No & 11 & 23.9 \\
\hline
\end{tabular}




\section{Instrument}

The research instrument of this study was a self-designed questionnaire by the researchers based on several previous studies (Hadley and Sheingold 1993; Williams 1995; Pelgrum 2001; Turbill 2001; Sandberg 2002; Butler and Sellbom 2002; Becta 2004; Schoepp 2005; Wood et al. 2008; Ihmeideh 2009; Al-Senaidi et al. 2009; Bingimlas 2009; Alwani and Soomro 2010; Khan et al. 2012; Chen et al. 2012; Goktas et al. 2013; Nikolopoulou and Gialamas 2013). Two sections were included in this questionnaire: (1) Basic personal information of early childhood teachers. It involved the gender, age, teaching years, educational level, pre-service training on ICT (Yes/ No), in-service training on ICT (Yes/No), and ICT use in daily life (Yes/No); (2) Barriers that early childhood teachers may encounter in the process of ICT integration in teaching. This section included 21 barriers which could be divided into five groups: (1) The first group included eight statements (S1, S2, S3, S4, S5, S6, S10, S11) related to lack of equipment and resources; (2) The second group included five statements (S8, S9, S13, S20, S21) related to lack of support (technical, pedagogical, administrative, and parental); (3)The third group included four items (S7, S17, S18, S19) related to lack of skills, support, interests, and positive attitudes of teachers; (4) The fourth group involved three items (S14, S15, S16) related to the impacts of organizational environment (time/space/examination); (5) The last group included one statement (S12) related to the own characteristics of ICT (that is, "it is difficult to integrate ICT"). The participants were requested to choose their perceptions of these statements on a four-point Likert scale: 1 (a lot), 2 (partially), 3 (a little), and 4 (not at all).

\section{Procedure}

The process of data collection lasted from October 2013 to February 2014. The researchers firstly selected the three cities. Then they chose one early childhood setting from each city. All the questionnaires were administered to and returned from the early childhood teachers by e-mail.

The researchers used SPSS 20 (in Chinese) to manage and analyze the data. More specifically, for the analysis of the participating teachers' basic personal information and the main barriers they encountered, the researchers adopted the basic descriptive analysis. In order to examine the validity and reliability of the scale, the item analysis, principal component analysis, and Cronbach alpha analysis were used. Moreover, the multiple regression analysis was adopted to identify the impacts of the participating teachers' demographic characteristics on their perceptions of the barriers.

\section{Results}

Demographic information of the participating teachers

Table 1 presented the demographic characteristics of the participating teachers. It can be seen that all the teachers were female. The majority of them $(93.3 \%)$ were 
aged $21-35$. And most of them $(90.5 \%)$ had $1-5$ years $(78.6 \%)$ or $6-10$ years $(11.9 \%)$ of working experience.

With regard to the educational level, $48.9 \%$ of the teachers were Bachelor degree holders, while more than a half of them $(51.1 \%)$ held a degree below Bachelor. No teachers had Master or Doctor degree.

The percentage of the teachers who attended pre-service training on ICT was low, with only $54.5 \%$. In addition, only $41.7 \%$ of the teachers attended in-service training on ICT in the past two years.

The proportion of the teachers who used ICT in their daily life was very high, with $76.1 \%$.

Measure of the validity and reliability of the scale

Initially, in order to identify the extent of discrimination of each item in the scale, a item analysis was adopted. The $\mathrm{T}$ values of items $\mathrm{S} 3(T=1.406 ; P=.178>.05)$, S4 $(T=1.897 ; P=.074>.05), \mathrm{S} 5(T=1.714 ; P=.104>.05), \mathrm{S} 14(T=.264$; $P=.796>.05), \mathrm{S} 15(T=1.018 ; P=.328>.05)$ in the independent sample $T$ test were not significant, which indicates that these five items could not discriminate well the responses from different respondents. However, the rest items of the scale had a high discrimination, with significant $\mathrm{T}$ values $(P<.05)$. Thus, these five items were removed from the scale by the researchers, and a total of 16 items were finally retained in the scale

The researchers then conducted a principal component analysis with the 16 items to reveal the factor structure of the scale. From Table 2, it can be seen that a total of three factors were identified. The first factor (F1), labeled "lack of support", included three items S8, S7, and S9. The second factor (F2), which was labeled "lack of equipment and resources", was composed of seven items S2, S10, S1, S12, $\mathrm{S} 6, \mathrm{~S} 13$, and S11. Besides, the third factor (F3) which was associated with six items S19, S20, S17, S16, S21, and S18 was labeled "lack of teachers' interest, support, and other external conditions".

Furthermore, a Chronbach alpha test was used to analysis the internal consistency of the independent factor and the overall scale (Table 2). The Chronbach alpha coefficients of the independent factor ranged from .894 to .937 , which indicated a high internal consistency of each factor. Meanwhile, the overall scale also showed a high internal consistency, with a high Chronbach alpha coefficient $(a=.907)$.

Main barriers to ICT integration in teaching of the early childhood teachers

Table 3 presented the details of the means, standard deviations, and percentages of the 16 barriers perceived by the participants. The results indicated that the top barrier perceived by the teachers was "lack of content/material" $(M=1.98)$. Other leading barriers referred to "lack of pedagogical models" $(M=2.17)$, "lack of laptops/notebooks" ( $M=2.19)$, and "lack of computers" $(M=2.19)$. However, "lack of support of teachers" $(M=3.38)$, "lack of interest of teachers" $(M=3.17)$, as well as "lack of support of parents" $(M=3.07)$ were the least prominent barriers. 
Table 2 Factor loadings, means and standard deviation of each item (16 items)

\begin{tabular}{|c|c|c|c|c|c|}
\hline \multirow[t]{2}{*}{ Barriers } & \multicolumn{3}{|c|}{ Factors } & \multirow[t]{2}{*}{ M } & \multirow[t]{2}{*}{ SD } \\
\hline & F1ds & F2 & F3 & & \\
\hline S8 Lack of technical support & .927 & & & 2.62 & 1.067 \\
\hline S7 Lack of skills of teachers & .898 & & & 2.74 & .938 \\
\hline S9 Lack of pedagogical support & .845 & & & 2.69 & 1.004 \\
\hline S2 Lack of laptops/notebooks & & .924 & & 2.18 & 1.073 \\
\hline S10 Lack of content/material & & .831 & & 1.95 & 1.025 \\
\hline S1 Lack of computers & & .810 & & 2.15 & .961 \\
\hline S12 Difficult to integrate ICT & & .736 & & 2.21 & 1.080 \\
\hline S6 Computers lacking update/repair & & .656 & & 2.56 & .718 \\
\hline S13 Lack of pedagogical models & & 616 & & 2.21 & .923 \\
\hline S11 Lack of content in national language & & .582 & & 2.33 & .772 \\
\hline S19 No clear benefit to use ICT & & & .832 & 2.87 & .923 \\
\hline S20 Lack of support of parents & & & .798 & 3.08 & .984 \\
\hline S17 Lack of support of teachers & & & .796 & 3.38 & .847 \\
\hline S16 Pressure for exams and tests & & & .761 & 2.69 & .950 \\
\hline S21 Not a goal in the school & & & .726 & 2.85 & 1.065 \\
\hline S18 Lack of interest of teachers & & & .719 & 3.18 & .854 \\
\hline Chronbach alpha & .937 & .894 & .901 & & \\
\hline Overall chronbach alpha & .907 & & & & \\
\hline
\end{tabular}

Factor 1 (F1): Lack of support; Factor 2 (F2) Lack of equipment and resources, Factor 3 (F3) Lack of teachers' interest, support and other external conditions

Impacts of demographic characteristics on the early childhood teachers' perceptions of barriers

The impacts of demographic characteristics on the participating teachers' perceptions of barriers were analyzed by the multiple regression analysis with a stepwise approach (Table 4). The independent variables (X) included teachers' "age", "teaching experience", "educational level", "pre-service training on ICT", "inservice training on ICT", and "ICT use in daily life". Meanwhile, a total of four dependent variables (Y) were involved, which specifically were teachers' perceptions of the barrier "lack of support" (F1), of the barrier "lack of equipment and resources" (F2), of the barrier "lack of teachers' interest, support and other external conditions" (F3), as well as of "the whole barriers". The multiple regression analysis was conducted four times based on different dependent variables, and each time the six independent variables were all involved.

For the dependent variables F1 and F2, only the independent variable "ICT use in daily life" entered the equation $(F=15.480 ; P=.000<.05)$. Other independent variables were excluded. This variable could explain $34.0 \%$ of the variance of $\mathrm{F} 1$ $\left(R^{2}=.340\right)$, and $24.5 \%$ of the variance of $\mathrm{F} 2\left(R^{2}=.245\right)$. Furthermore, this variable had a significant negative influence on F1 $(B=-3.652 ; T=-3.934$; 
Table 3 Main barriers perceived by the early childhood teachers

\begin{tabular}{|c|c|c|c|c|c|c|c|}
\hline \multirow[t]{2}{*}{ Barriers } & \multirow[t]{2}{*}{$\mathrm{N}$} & \multirow[t]{2}{*}{ M } & \multirow[t]{2}{*}{ SD } & \multicolumn{4}{|l|}{$\%$} \\
\hline & & & & LO & PA & LI & NA \\
\hline S10 Lack of content/material & 41 & 1.98 & 1.060 & 41.5 & 34.1 & 9.8 & 14.6 \\
\hline S13 Lack of pedagogical models & 41 & 2.17 & .919 & 22.0 & 51.2 & 14.6 & 12.2 \\
\hline S2 Lack of laptops/notebooks & 42 & 2.19 & 1.087 & 33.3 & 31.0 & 19.0 & 16.7 \\
\hline S1 Lack of computers & 42 & 2.19 & .994 & 31.0 & 28.6 & 31.0 & 9.5 \\
\hline S12 Difficult to integrate ICT & 41 & 2.20 & 1.077 & 36.6 & 19.5 & 31.7 & 12.2 \\
\hline S11Lack of content in national language & 41 & 2.32 & .756 & 4.9 & 70.7 & 12.2 & 12.2 \\
\hline S6 Computers lacking update/repair & 42 & 2.57 & .703 & 2.4 & 47.6 & 40.5 & 9.5 \\
\hline S8 Lack of technical support & 42 & 2.60 & 1.061 & 16.7 & 33.3 & 23.8 & 26.2 \\
\hline S9 Lack of pedagogical support & 42 & 2.67 & .979 & 9.5 & 40.5 & 23.8 & 26.2 \\
\hline S16 Pressure for exams and tests & 42 & 2.67 & .979 & 9.5 & 40.5 & 23.8 & 26.2 \\
\hline S7 Lack of skills of teachers & 44 & 2.68 & .934 & 6.8 & 43.2 & 25.0 & 25.0 \\
\hline S19 No clear benefit to use ICT & 42 & 2.81 & .943 & 11.9 & 19.0 & 45.2 & 23.8 \\
\hline S21 Not a goal in the school & 42 & 2.83 & 1.080 & 11.9 & 31.0 & 19.0 & 38.1 \\
\hline S20 Lack of support of parents & 42 & 3.07 & 1.022 & 11.9 & 11.9 & 33.3 & 42.9 \\
\hline S18 Lack of interest of teachers & 42 & 3.17 & .853 & 2.4 & 21.4 & 33.3 & 42.9 \\
\hline S17 Lack of support of teachers & 42 & 3.38 & .854 & 0 & 23.8 & 14.3 & 61.9 \\
\hline
\end{tabular}

LO A Lot, PA Partially, LI A Little, NA Not At All

Table 4 Impacts of demographic characteristics on the participants' perceptions of barriers

\begin{tabular}{llllllll}
\hline $\mathrm{Y}$ & $\mathrm{X}$ & $\mathrm{R}$ & $\mathrm{R}^{2}$ & $\mathrm{~F}$ & $\mathrm{~B}$ & $\mathrm{~T}$ & Sig. \\
\hline F1 & ICT use in daily life & .583 & .340 & 15.480 & -3.652 & -3.934 & .000 \\
F2 & ICT use in daily life & .494 & .245 & 8.739 & -6.167 & -2.956 & .006 \\
Overall & ICT use in daily life & .580 & .337 & 13.702 & -13.446 & -3.702 & .001 \\
\hline
\end{tabular}

$Y$ Dependent Variables, $X$ Independent Variables

Sig. $=.000<.05)$, and F2 $(B=-6.167 ; T=-2.956$; Sig. $=.006<.05)$. This finding means that the teachers who used ICT in their daily life had more probability to perceive F1 and F2 as barriers than those who did not use ICT in their daily life. In addition, no independent variables were found to have significant impacts on F3.

The independent variable "ICT use in daily life" was also found to have a significant negative impact on teachers' perceptions of the whole barriers $(B=-13.446$; $T=-3.702 ;$ Sig. $=.001<.05)$. More specifically, the teachers who used ICT in their daily life were more likely to perceive all the items in the scale as barriers than those who did not used ICT in their daily life. Only this independent variable entered the equation in the analysis $(F=13.702$; Sig. $=.001<.05)$. The determination coefficient $\left(R^{2}\right)$ of this variable was .337 , which indicates that the independent variable "ICT use in daily life" could explain $33.7 \%$ of variance of the dependent variable "teachers' perceptions of the whole barriers". 


\section{Conclusions and discussions}

The purpose of this study was to investigate and analyze the barriers to ICT integration in teaching from a perspective of Chinese early childhood teachers in Mainland China, to which was paid less attention by previous Chinese researchers. A total of two questions were looked at: one was what are the top barriers to ICT integration in teaching perceived by Mainland Chinese early childhood teachers; the other one was how Mainland Chinese early childhood teachers' demographic information impact their perceptions of barriers to ICT integration in teaching. In order to answer these questions, a self-designed questionnaire was adopted as the research instrument, and was administered into three early childhood settings located in three different cities in terms of the administrative division. Finally, 46 questionnaires were selected for further analysis.

Through identifying the top barriers and analyzing the influencing factors of perceived barriers is helpful to effectively solve these barriers, and further to improve the level of Mainland Chinese early childhood teachers' ICT integration in their teaching practices. In addition, this study may also provide some implications for the global trend of ICT introduction and integration in the education field, in particular for the developing countries.

Top barriers perceived by the early childhood teachers

The leading barriers perceived by the participating teachers on ICT integration in teaching included lack of content/material, lack of pedagogical models, lack of laptops/notebooks, and lack of computers. On the contrary, lack of support of teachers, lack of interest of teachers, and lack of support of parents were the least prominent barriers.

According to the theory of Ertmer (1999), the leading barriers perceived by the participating teachers belong to the first-order barriers, specifically referring to lack of hardware (laptops, notebooks, and computers), software (teaching content and material), and pedagogical support (pedagogical models). This finding is consistent with many previous studies both in general education and in early childhood education (Sandberg 2002; Butler and Sellbom 2002; Becta 2004; Wood et al. 2008; Al-Senaidi et al. 2009; Bingimlas 2009; Ihmeideh 2009; Alwani and Soomro 2010; Khan et al. 2012; Goktas et al. 2013; Nikolopoulou and Gialamas 2013). However, most of the second-order barriers mentioned by this study were perceived as the least main barriers by the participating teachers, which involved lack of teachers' interests, and lack of teachers' support. This finding was also identified by several other studies (Wood et al. 2008; Ihmeideh 2009; Bingimlas 2009).

Impacts of demographic characteristics on the early childhood teachers' perceptions of barriers

Through the item analysis and principal component analysis of the scale, 16 items and three factors were identified. These three factors were separately labeled "lack 
of support" (F1), "lack of equipment and resources" (F2), and "lack of teachers' interest, support and other external conditions" (F3). A regression analysis was then conducted to identify the impacts of the demographic characteristics on the participating teachers' perceptions of the three factors, as well as on their overall perceptions of the barriers.

From the perspective of the overall barriers, only the independent variable "ICT use in daily life" had a significant impact on the participating teachers' perceptions of them. Using ICT in daily life made the teachers more likely to perceive the items mentioned by this study as barriers.

From a specific perspective of the barriers, the independent variable "ICT use in daily life" was also found significantly influence the participating teachers' perceptions of the factor "lack of support" (F1) and the factor "lack of equipment and resources" (F2). The teachers using ICT in their daily life were more likely to perceive these two factors as barriers. No independent variables were identified to have significant impacts on the teachers' perceptions of "lack of teachers' interest, support and other external conditions" (F3).

In conclusion, when several second-order barriers, such as lack of teachers' interest, and lack of teachers' support were not perceived as main barriers by the participating teachers, a broad range of first-order barriers which are more basic, such as lack of hardware, lack of software and lack of pedagogical support, had still not been solved in the relevant early childhood settings. Furthermore, the variable "ICT use in daily life" played an important role in determining the participating teachers' perceptions of barriers both on the overall level and on the specific level, to which should be paid attention by related stakeholders.

\section{Recommendations}

Based on the findings and conclusions mentioned above, several strategies are recommended.

- Sufficient ICT-related equipment and curriculum resource/content should be provided to these teachers. In addition, it is also very important to provide several pedagogical supports in order to help them know about how to leverage ICT in their teaching activities.

- Effective and quality pre-service and in-service training is needed. This kind of training needs to be focused on helping the teachers to form modern learning and teaching philosophies, methods and practices, such as student-centered learning and teaching, especially when early childhood settings intent to attain a higher level of ICT integration in teaching.

- First-order barriers and second-order barriers, even the newly mentioned thirdorder barrier need to be addressed simultaneously. A number of literature both in general education and in early childhood education pointed out that the relationship between barriers to ICT integration in teaching was very complex (Ertmer 1999; Bingimlas 2009; Blackwell et al. 2013), and were closely interrelated (Ertmer 1999; Becta 2004; Goktas et al. 2013). Thus, the most efficient way to overcome these barriers was to focus on both the first-order 
barriers and the second-order barriers, as well as other barriers which may hinder teachers' successful ICT integration in their teaching practices.

- The factor influencing the teachers' perceptions of barriers to ICT integration in teaching should also be considered in order to make effective and targeted measures to cope with and solve the barriers to ICT integration in teaching, such as "ICT use in daily life" in this study.

\section{Limitations and future research}

The limitations of this study include: (1) Variables selection. Twenty one variables on barriers to ICT integration in teaching were selected by the researchers. Other variables both on first-order barriers and second-order barriers were not involved, such as curriculum constraint, school culture, teachers' beliefs on teaching and established teaching practices, and teachers' confidence of ICT integration in teaching, etc. (2) Sample selection. Only 46 early childhood teachers from three early childhood settings in three different cities participated in this study. The majority of them were young teachers aged 21-35 with 0-10 years of working experience. Besides, most of them held Bachelor degree or below. This will affect the generalization of the findings of this study. (3) Data collection. The questionnaire was the only research instrument for collecting data. Thus, future studies can involve more variables of barriers, larger, and more diverse early childhood settings and samples to verify the findings of this study. Moreover, the mixed research method (quantitative and qualitative approaches) is also recommended in order to obtain a better understanding of the barriers.

Furthermore, a number of research topics can be explored in the future research. They include: (1) What are other practitioners' (e.g., educational administrator; principals) perceptions of barriers to ICT integration in early childhood education? (2) How early childhood teachers' perceptions of barriers change after removing first-order barriers? (3) Are there some differences on early childhood teachers' perceived barriers to ICT integration in teaching among different regions, cities and early childhood settings in Mainland China? (4) What is the particularity of the barriers encountered by early childhood teachers compared with the teachers in other educational settings? (5) What is the particularity of the barriers encountered by the Mainland Chinese early childhood teachers compared with the teachers in other countries? etc.

Acknowledgments We would like to thank all the teachers who participated in this study, and our colleagues who helped us to finish this research. Special thanks are given to the anonymous reviewers and the editor.

\section{References}

Al-Senaidi, S., Lin, L., \& Poirot, J. (2009). Barriers to adopting technology for teaching and learning in Oman. Computers \& Education, 53(3), 575-590. 
Alwani, A. E. S., \& Soomro, S. (2010). Barriers to effective use of Information Technology in science education at Yanbu Kingdom of Saudi Arabia. Resource document. http://cdn.intechopen.com/ pdfs-wm/10062.pdf. Accessed 4 Sept 2014.

American Academy of Pediatrics. (2013). Children, adolescents, and the media: Counsel on communications and media. Resource document. http://pediatrics.aappublications.org/content/early/ 2013/10/24/peds.2013-2656.full.pdf+html. Accessed 28 July 2014.

Becta. (2004). A review of the research literature on barriers to the uptake of ICT by teachers. Resource document. http://dera.ioe.ac.uk/1603/1/becta_2004_barrierstouptake_litrev.pdf. Accessed 25 July 2014.

Bingimlas, K. A. (2009). Barriers to the successful integration of ICT in teaching and learning environments: A review of the literature. Eurasia Journal of Mathematics, Science \& Technology Education, 5(3), 235-245.

Blackwell, C. K., Lauricella, A. R., \& Wartella, E. (2014). Factors influencing digital technology use in early childhood education. Computers \& Education, 77, 82-90.

Blackwell, C. K., Lauricella, A. R., Wartella, E., Robb, M., \& Schomburg, R. (2013). Adoption and use of technology in early education: The interplay of extrinsic barriers and teacher attitudes. Computer \& Education, 69, 310-319.

Buckingham, D. (2007). Beyond technology: Childre's learning in the age of digital culture. Cambridge, UK: Polity.

Butler, D. L., \& Sellbom, M. (2002). Barriers to adopting technology for teaching and learning. Educause Quarterly, 2, 22-28.

Chen, W., Tan, A., \& Lim, C. (2012). Extrinsic and intrinsic barriers in the use of ICT in teaching: A comparative case study in Singapore. In M. Brown, M. Hartnett, \& T. Stewart (Eds.), Future challenges, sustainable futures. New Zealand: Wellington.

Ertmer, P. A. (1999). Addressing first-and second-order barriers to change: Strategies for technology integration. Educational Technology Research and Development, 47(4), 47-61.

Evangelopoulou, P. (2014). Educators' attentive use key to maximizing ICT benefits in early years education. Resource document. http://www.unescobkk.org/education/ict/online-resources/databases/ ict-in-education. http://www.database/item/article/educators-attentive-use-key-to-maximizing-ictbenefits-in-early-years-education/ Accessed 20 July 2014.

Goktas, Y., Gedik, N., \& Baydas, O. (2013). Enablers and barriers to the use of ICT in primary schools in Turkey: A comparative study of 2005-2011. Computers \& Education, 68, 211-222.

Guo, L., Qian, Q., Wang, J., \& Zeng, Z. (2006). Investigation and analysis of kindergartens' IT use in Shanghai [in Chinese: 上海市幼儿园应用信息技术的调查与分析]. Shanghai Research on Education, 6, 37-40.

Hadley, M., \& Sheingold, K. (1993). Commonalities and distinctive patterns in teachers' integration of computers. American Journal of Education, 101(3), 261-315.

Ihmeideh, F. M. (2009). Barriers to the use of technology in Jordanian pre-school settings. Technology, Pedagogy and Education, 18(3), 325-341.

Khan, M. S. H., Hasan, M., \& Clement, C. K. (2012). Barriers to the introduction of ICT into education in developing countries: The example of Bangladesh. International Journal of Instruction, 5(2), 61-80.

Kozma, R. B. (2008). Comparative analysis of policies for ICT in education. In J. Voogt \& G. Knezek (Eds.), International handbook of information technology in primary and secondary education. New York: Springer.

Leu, D. J., \& Leu, D. D. (1997). Teaching with the Internet: Lessons from the classroom. Norwood, MA: Christopher-Gordon.

Liu, Z. (2007). The situation and solutions of preschool educational informationization in Zhejiang province [in Chinese: 浙江省学前教育信息化现状的现状分析及对策研究]. China Educational Technology, 8, 34-38.

Liu, X., Toki, E. I., \& Pange, J. (2014). The use of ICT in preschool education in Greece and China: A comparative study. Procedia-Social and Behavioral Sciences, 112, 1167-1176.

Meng, H., Kong, X., \& Qian, L. (2011). Questions and solutions of preschool teachers' Information Technology training-based on the investigation of status of preschool teachers' Information Technology skills in Hebei province [in Chinese: 幼儿教师信息技术培训问题及对策研究-基于 河北省幼儿教师信息技术技能的现状调查]. Journal of Adult Education of Hebei University, 13 (1), 61-62.

Ministry of Education of the People's Republic of China. (2010). National medium-and long-term plan for educational reform and development. Resource document. http://planipolis.iiep.unesco.org/upload/ 
China/China_National_Long_Term_Educational_Reform_Development_2010-2020.pdf. Accessed on 28 May 2014.

Ministry of Education of the People's Republic of China. (2012). Professional standards for kindergarten teachers. Resource document. http://www.moe.edu.cn/publicfiles/business/htmlfiles/moe/s6991/ 201212/xxgk_145603.html. Accessed on 28 May 2014.

National Association for the Education of Young Children. (2010). Technology and interactive media as tools in early childhood programs serving children from birth through age 8. Resource document. http://www.naeyc.org/content/technology-and-young-children. Accessed 28 July 2014.

Nikolopoulou, K., \& Gialamas, V. (2013). Barriers to the integration of computers in early childhood settings: Teachers' perceptions. Education and Information Technologies, doi:10.1007/ s10639-013-9281-9.

Pelgrum, W. J. (2001). Obstacles to the integration of ICT in education: Results from a worldwide educational assessment. Computers \& Education, 37(2), 163-178.

Pelgrum, W. J., \& Law, N. (2003). ICT in education around the world: Trends, problems and prospects. Paris: UNESCO.

$\mathrm{Pu}, \mathrm{Y}$. (2005). Improve information literacy and promote preschool teachers' professional development [in Chinese]. Shanghai Research on Education, 11, 94-95.

Redecker, C. (2009). Review of learning 2.0 practices: Study on the impact of Web 2.0 innovations. Resource document. http://ftp.jrc.es/pub/EURdoc/JRC49108.pdf. Accessed 4 Sep 2014.

Sandberg, A. (2002). Preschool teacher's conceptions of computers and play. Information Technology in Childhood Education Annual, 2002(1), 245-262.

Schoepp, K. (2005). Barriers to technology integration in a technology-rich environment. Learning and Teaching in Higher Education: Gulf Perspectives, 2(1), 1-24.

Searson, M., Laferriere, T., \& Nikolow, R. (2011). Barriers to successful implementation of technology integration in educational settings. Resource document. http://rnikolov.unibit.bg/publications/22/ TWG7_JCAL_V2.2[1].pdf. Accessed 22 July 2014.

Tsai, C. C., \& Chai, C. S. (2012). The "third"-order barrier for technology-integration instruction: Implications for teacher education. Australasian Journal of Educational Technology, 28(6), 10571060.

Turbill, J. (2001). A researcher goes to school: Using technology in the kindergarten literacy curriculum. Journal of Early Childhood Literacy, 1(3), 255-279.

Umayahara, M. (2014). Benefits and risks of ICT use in early childhood. Resource document. http://www.unescobkk.org/education/ict/online-resources/databases/ict-in-education. http://www. database/item/article/benefits-and-risks-of-ict-use-in-early-childhood/. Accessed 20 July 2014.

Williams, B. (1995). Factors contributing to successful implementation of computer technology in schools. Dissertation Abstracts International, 56(8), 3092.

Wood, E., Specht, J., Willoughby, T., \& Mueller, J. (2008). Integrating computer technology in early childhood education environments: Issues raised by early childhood educators. The Alberta Journal of Educational Research, 54(2), 210-226.

Xia Liu is a PhD candidate of Department of Early Childhood Education, School of Education, University of Ioannina, Greece. She is also a PhD candidate of School of Education, Northeast Normal University, China. Her research interests cover ICT use in education, early childhood education, and educational policy.

Jenny Pange is a professor of Department of Early Childhood Education, School of Education, University of Ioannina, Greece. Besides, she is also the director of Laboratory of New Technology and Distance learning of University of Ioannina, Greece. Her research interests include educational technology, educational informatics, and educational statistics. 